\title{
ОПЫТ СОЗДАНИЯ ОНЛАЙН-КУРСОВ ПРИ РЕАЛИЗАЦИИ ОБРАЗОВАТЕЛЬНЫХ ПРОГРАММ РАЗНОГО УРОВНЯ
}

\author{
Килейников Д.В., Подачина С.В., Бирюкова Е.В., Мкртумян А.М., Маев И.В.
}

ФГБОУ ВО «Московский государственный медико-стоматологический университет имени А.И. Евдокимова» Минздрава России, Москва

В рамках федерального проекта «Молодые профессионалы» национального проекта «Образование» к 2024 году не менее 20\% обучающихся по образовательным программам высшего образования должны осваивать отдельные онлайн-курсы с использованием ресурсов иных организаций, осуществляющих образовательную деятельность. В последнее время широко дискутировался вопрос о применении дистанционных образовательных технологий в подготовке медицинских работников. Но в связи с введением ограничительных мер в условиях угрозы распространения новой коронавирусной инфекции COVID-19, образовательные организации одномоментно перешли на обучение с использованием дистанционных технологий и электронного бучения.

ЦЕЛЬ: внедрить дистанционные образовательные технологии в образовательные программы разного уровня.

МАТЕРИАЛЫ И МЕТОДЫ: в рамках проекта «Цифровой университет» разработана оригинальная информационная платформа дистанционного образования, интегрированная с порталом «Современная цифровая образовательная среда Российской Федерации». Она позволяет изучать онлайн-курсы с использованием любых устройств.

РЕзУЛЬТАТЫ: на кафедре эндокринологии и диабетологии университета созданы онлайн-курсы в рамках основных и дополнительных профессиональных образовательных программ разного уровня, актуальные по содержанию, соответствующие приоритетным направлениям развития медицины и здравоохранения и направленные на формирование компетенций, в соответствии с федеральными государственными образовательными стандартами высшего образования.

Структура курса состоит из модулей, в рамках каждого из которых обучающимся предлагается создание индивидуальных образовательных траекторий, позволяющих применять нетипичные для высшего медицинского образования виды коммуникации между субъектами образовательного процесса, способствующие формированию и развитию коммуникативных компетенций.

Курсы основаны на инновационных и креативных визуальных образовательных технологиях. При этом используются такие формы проведения занятий как видеолекции, презентации с алгоритмами оказания медицинской помощи, видеомастер-классы с демонстрацией практических манипуляций и клинических случаев, ролевые игры с разбором клинических ситуаций, проверка и самопроверка с помощью тестирования и ситуационных задач, интерактивные квесты, иллюстративные видео- и фотоматериалы, консультативные и дискуссионные вебинары. Качество освоения каждой темы и курса в целом измеряется с помощью блока заданий в тестовой форме, практических заданий и ситуационных задач. Онлайн-курсы позволяют представить сложный и объемный материал в удобной форме, не упрощая его, одновременно сохраняя качество традиционной формы обучения.

ВЫводы: безусловно, подготовка медицинских работников невозможна исключительно с применением дистанционных образовательных технологий и электронного обучения (это запрещено и законодательством). Однако накопленный нами опыт позволяет определить место дистанционных образовательных технологий в структуре медицинских образовательных программ разного уровня образования, максимально эффективно и рационально использовать их определенные преимущества, а также быть готовыми к быстро меняющимся условиям осуществления образовательного процесса, при этом сохранив качество подготовки обучающихся и выпускников. 